\title{
Effect of Different Soil Saturation Conditions on The Ultimate Uplift Resistance of Helical Pile Model
}

\author{
Mahmood R. Mahmood ${ }^{1, a^{*}}$, Nahla M. Salim ${ }^{1, b}$, and Ammar A. Al-Gezzy ${ }^{1, \mathrm{c}}$ \\ ${ }^{1}$ Civil Engineering Department, University of Technology-Iraq, Baghdad, Iraq. E-mail

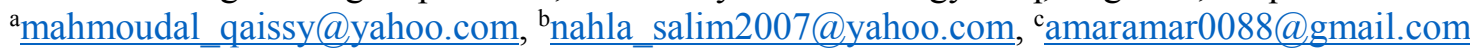

\begin{abstract}
Helical piles have many properties over the other types of piles systems include high tensile capabilities, the possibility of fast installation, applying load immediately after installation, and suitability for most soil's condition. In addition to that, helical piles have relatively less noise during installation; they represent a cost-effective alternative to conventional pile types. The use of helical piles grows in the world in the last fifty years. Many studies concentrate on the performance of this type of piles in fully saturated and dry soils. The achievement of the helical pile in unsaturated soils is rarely studied. So, to cover this small-scale demand model of the helical pile with double helices has been tested. Twenty tests were performed on three different models (pile with single helix, pile with double helices, and pile with triple helices) and pile shaft only, embedded in different conditions of soil saturation (fully saturated, partially saturated, and dry soils) under uplift loading. Three different matric suction of partial saturation were used of $6.5,7.4$, and $9.6 \mathrm{kPa}$. The results obtained from the tests showed that the highest value in the unsaturated soil was at suction $6.5 \mathrm{kPa}$ compared to other soil saturation conditions. The results mention that model piles embedded in dry soil have lower values of ultimate uplift capacities. The increment in uplift resistance of additional helices of single double and triple helices than that of shaft pipe embedded within dry soil shows an increment by approximately about 170,240 , and $282 \%$ respectively, for fully saturation soil, the increment about 342,463 , and $585 \%$ respectively, and by about 400,429 , and $475 \%$ respectively for matric suction of $6.5 \mathrm{kPa}$.
\end{abstract}

Keywords: Helical piles; partially saturation; pile resistance; uplift bearing capacity; spacing ratio; matric suction.

\section{Introduction}

More than a hundred years ago, helical piles were used and have good resistance to uplift load; various applications are used in different soil conditions [1]. Usually, the conventional piles installation boring or driving (placement or displacement) at a certain depth creates noise, vibration, and some effects on the surrounding structures and environment [2]. A helical pile is installed by applying vertical load with a torque without any disturbing [3]. The applied torque load can drive the pile to adequate depths, and some piles do not exceed the torque capabilities [4]. Perko [5] shows that for each revolution, the recommended rate of penetration is equal to one stage and the maximum uplift capacity of the piles depends on the spacing between helices, method of pile installation, and soil condition. This description illustrates the importance of the $(\mathrm{S} / \mathrm{D})$ ratio, which is defined as "the spacing ratio between two adjacent helix plates to the average diameter of these plates" [6]. The spacing ratio is present when the cylindrical shear method and the individual bearing method are changed [7]. Aydin et al. [8] showed that the change from the cylinder shear method to the individual method of loading occurs by a spacing ratio of (3). Tappenden et al. [9] confirmed using a cylindrical shear model when the adjacent helix plate diverged in $1.5 \mathrm{D}$, and $3 \mathrm{D}$ was required to change the failure mechanism. Lutenegger [10] showed that the spacing ratio of 2.25D controls the behavior of the pile as a cylindrical shear method, and when the spacing ratio exceeds $2.25 \mathrm{D}$, the individual bearing method is controlled. When the spacing ratio is less than $2 \mathrm{D}$, the failure is the cylinder shear.

Concerning partially saturated soil, the pile resistance increasing about (3-5) times the pile resistance in the same soil under saturated conditions [11]. Many researchers have concentrated on verifying this relation between soil and water. The entire behavior of unsaturated soil is different behavior as that of dry or saturated soil. The liquid may form a continuous stage or be separated from 
soil particles by other means [12]. Unsaturated soil can be classified according to the degree of saturation $\mathrm{Sr}$ [13]. The state of air and water phases in partially saturated soils can be described in reference [14], extremely dry $(\mathrm{Sr}<5 \%)$, dry of optimum $(5<\mathrm{Sr}<90 \%)$, at optimum $\mathrm{Sr}=90 \%$, wet of optimum $(\mathrm{Sr}>90 \%)$, and very wet $(\mathrm{Sr}>95 \%)$. The suction system mainly consists of two components, matric and osmotic [12]. Suction was defined as the water potential in a soil-water system [15]. This is another explanation in which retention and movement of soil-water and the mechanical behavior of unsaturated soils were described in terms of strength and deformation characteristics potential [16]. Richards [15] reported that three components control the suction. The first component is the capillary that is related to the dominating component of soil-water potential. Surface charges on mineral surfaces are the second component, and soil-water chemistry is the third component.

\section{Experimental Work}

The model tests consist of standard laboratory tests to predict the maximum lifting resistance of different screw pile models embedded within cohesionless soil with a relative density (Dr) of $50 \%$, under uplift force with various soil saturation conditions (fully saturated, dry, and partially saturated conditions).

Soil Properties. Fine River Sand was brought from Baghdad-Abu Nawas Street; soil standard tests were conducted in the Soil Mechanics Lab. at the University of Technology. Engineering, physical properties, and classification tests were predicted. The results are summarized in Table 1 and Figure 1. The engineering tests were prepared with a relative density of $50 \%$, which gives the dry unit weight of $16 \mathrm{kN} / \mathrm{m}^{3}$. Figure 1 shows the distribution grain size of the soil used, and according to USCS, "the soil is classified as SP".

Models for Helical Piles. Steel helical pile models are manufactured and fabricated with (single, double, and triple helices) according to the requirements: Inner shaft diameter $(20 \mathrm{~mm})$, pile shaft thickness $(1.5 \mathrm{~mm})$, helix diameter $(50 \mathrm{~mm})$, helix plates thickness $(2 \mathrm{~mm})$, The spacing between of helices $(150 \mathrm{~mm})$. Figure 2 shows helical pile models.

Table 1. Physical sand properties to use in work.

\begin{tabular}{|l|c|c|}
\hline \multicolumn{1}{|c|}{ The property } & Value & Specification \\
\hline Grain size distribution & SP & ASTM D422-00 [17] \\
\hline D10 $(\mathrm{mm})$ & 0.16 & - \\
\hline D30 $(\mathrm{mm})$ & 0.21 & - \\
\hline D60 $(\mathrm{mm})$ & 0.29 & - \\
\hline Angle of internal friction $\varphi$ for dry sand (degree) & 33 & - \\
\hline Angle of internal friction $\varphi$ for fully saturated sand $\left(^{\circ}\right)$ & 25 & - \\
\hline Soil classification, USCS & SP & - \\
\hline Specific gravity, Gs & 2.65 & ASTM D854-00 [18] \\
\hline Max. dry unit weight $\left(\mathrm{kN} / \mathrm{m}^{3}\right)$ & 17.4 & ASTM D4253-00 [19] \\
\hline Min. dry unit weight $\left(\mathrm{kN} / \mathrm{m}^{3}\right)$ & 14.8 & ASTM D4254-00 [20] \\
\hline Relative density, RD $(\%)$ & 50 & - \\
\hline
\end{tabular}




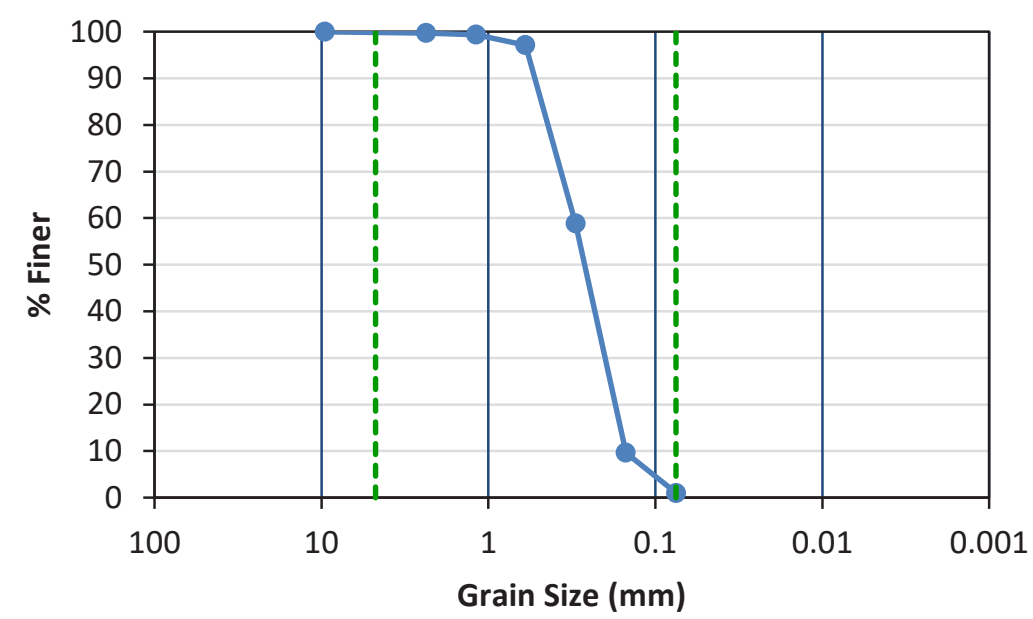

Figure 1. Grain size of the soil used in this study.

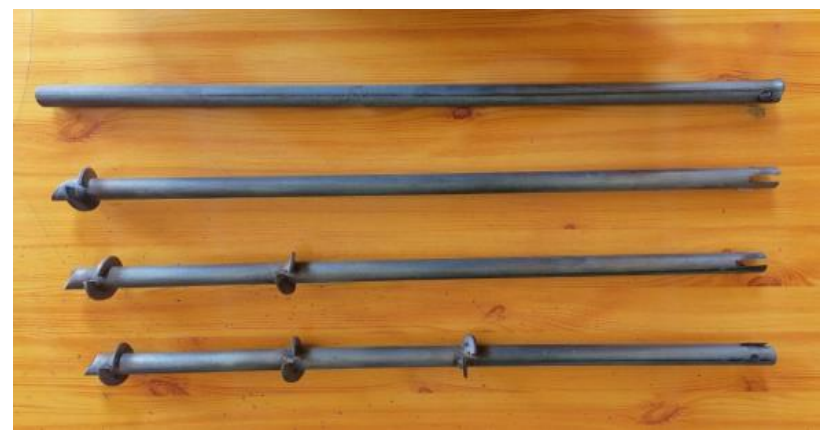

Figure 2. Helical pile models

Loading System. The setup apparatus shown in Figure 3 is used to test all helical piles and consist of a soil container of $(600 \times 600 \times 700 \mathrm{~mm})$, steel frame, load cell, load indicator, a system for (saturation and desaturation), load cell of (1) ton capacity for final load measurement used for the loading rate of $0.5 \mathrm{~mm} / \mathrm{min}$. Digital disk programmer for displacement measurement.

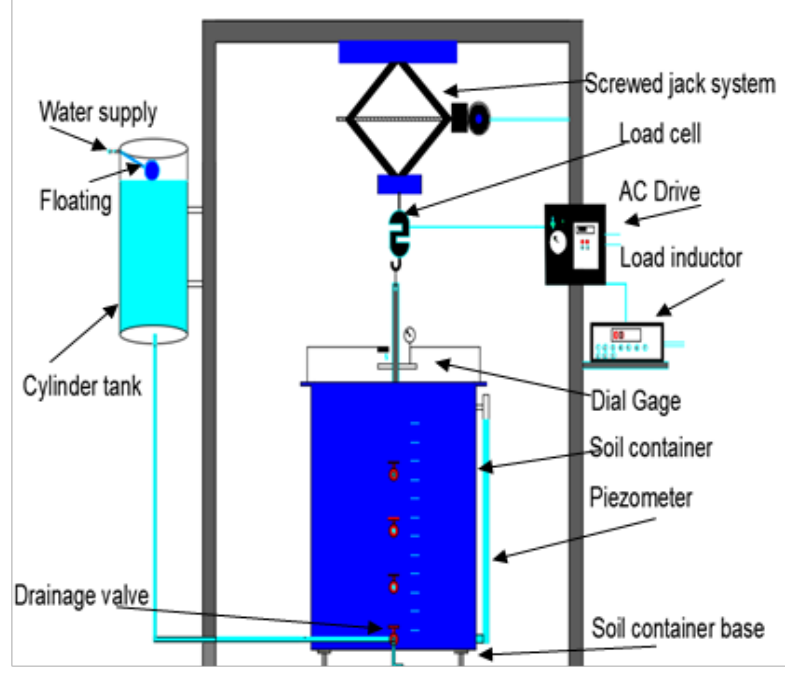

Figure 3. Frame and loading setup.

Measurement of Soil Suction. There are several different methods used for measuring soil suction, direct and indirect methods. In this study, a straightforward method was used to measure the negative pore pressure by using the Tensiometers apparatus. 
Saturation and Desaturation of Soil. The soil model was placed in a soil container of dimensions of $(600 \times 600 \times 700 \mathrm{~mm})$, a filter material of $150 \mathrm{~mm}$ thickness was used at the bottom of the container with a screen plate to get laminar flow during saturation and prevent erosion during discharge. Then the soil is placed in layers of $50 \mathrm{~mm}$ thickness to a chive a total height of $450 \mathrm{~mm}$ and a relative density of $(50 \%)$. Saturation of soil model provided by a controlled water tank, as shown in Figure 4. The water flows through the filter soil layer and rises from the bottom slowly until flooded, then left for 24 hours to achieve full saturation. Different unsaturation conditions were achieved by discharge the water from valves fixed at different levels, as shown in Figure 4. To achieve partial saturation of the upper soil layer of $150 \mathrm{~mm}$ thickness, the upper first valve is opened, and the Tensiometer is fixed at the mid-layer of $75 \mathrm{~mm}$ depth. After 24 hours, the suction is recorded. To achieve partial saturation to a depth of $300 \mathrm{~mm}$, the second valve at a depth of $300 \mathrm{~mm}$ was opened, and the Tensiometer is fixed at the mid-layer of $150 \mathrm{~mm}$ depth. After 24 hours, the suction is recorded. The same procedure was used to achieve partial saturation at a depth of $450 \mathrm{~mm}$, the third valve at a depth of $450 \mathrm{~mm}$ was opened, and the Tensiometer is fixed at the mid-layer of $225 \mathrm{~mm}$ depth 24 hours, the suction is recorded. Figure $4(a, b, c)$ shows the number and locations of Tensiometers within unsaturated soil and the suction value recorded for each layer.

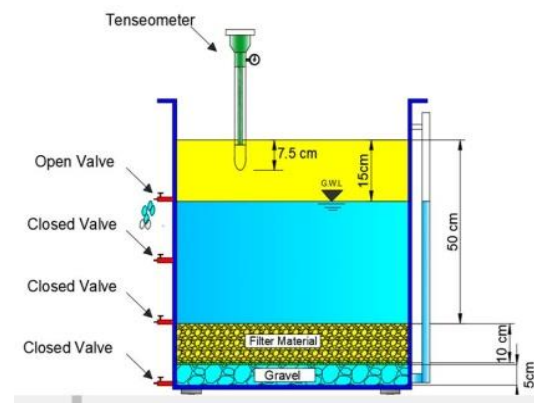

(a)

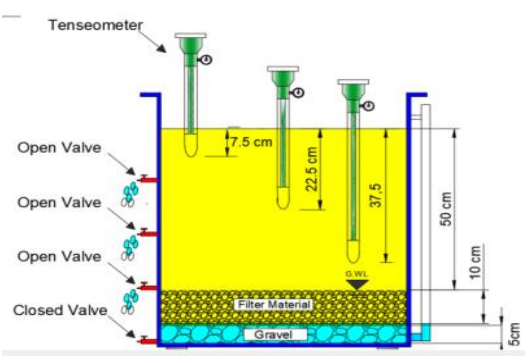

(b)

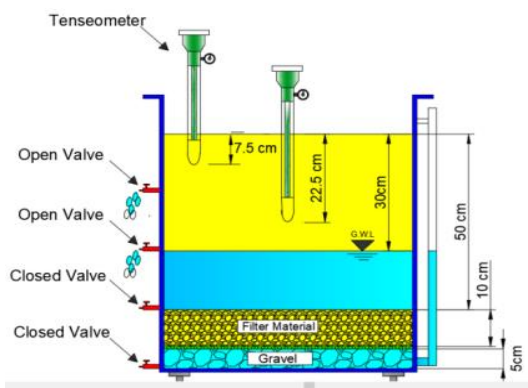

(c)

Figure 4. Profile suction of all stag.e

\section{Analysis and Discussion of the Result}

According to the water table, the suction profile set obtained by using a Tensiometer at the three different levels shows that the matric suction value increases with lowering the water level. Figure 5 shows the Tensiometers used with their accessories. Table 2 shows the average matric suction for the three stages.

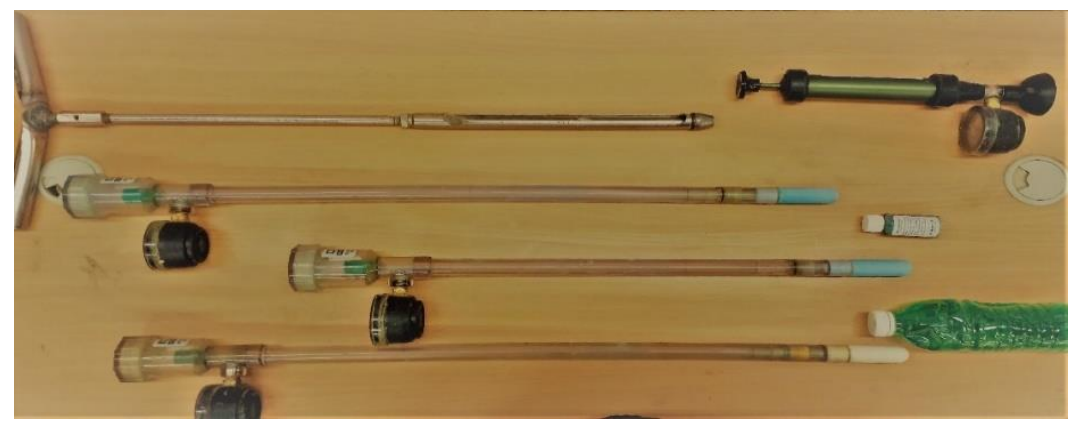

Figure 5. The three Tensiometers are used with their accessories.

Table 2. Average matric suction with reducing water level to achieve balance.

\begin{tabular}{|c|c|c|}
\hline Conditions of soil & Reduced water level from surface of the soil (mm) & $\begin{array}{c}\text { Average matric suction } \\
(\mathbf{k P a})\end{array}$ \\
\hline Fully saturated & 0.0 & 0.0 \\
\hline \multirow{3}{*}{ Partially Saturated } & 150.0 & 6.5 \\
\cline { 2 - 3 } & 300.0 & 7.4 \\
\cline { 2 - 3 } & 450.0 & 9.6 \\
\hline
\end{tabular}


SWCC Curve Prediction by Tensiometers. Soil Water Characteristic Curve SWCC of the adapted soil is measured by using a suction profile model at various depths, for example, $(75,150$, and 225) mm. Figures 6 and 7 show the SWCC as estimated by the equations of Fredlund et al. [21].

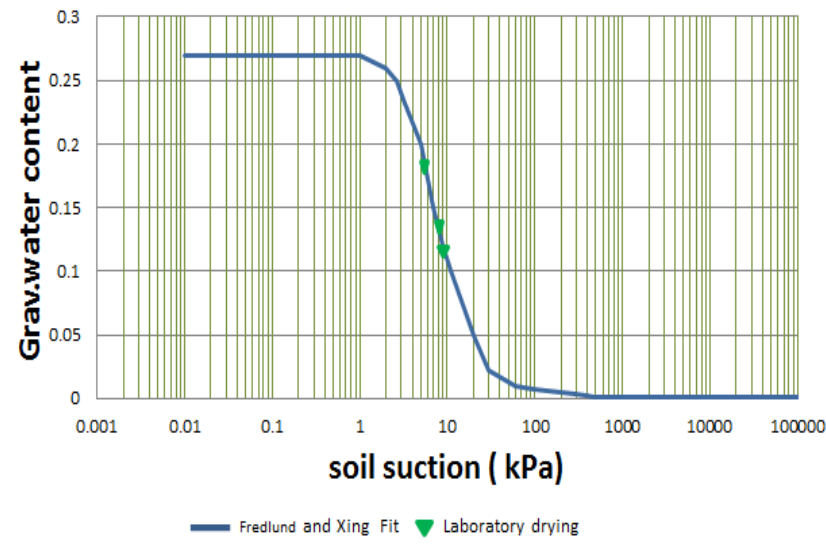

Figure 6. The relationship of gravitational water content and matric suction using the soil vision program adopted by Fredlund and Xing equation $[22]$.

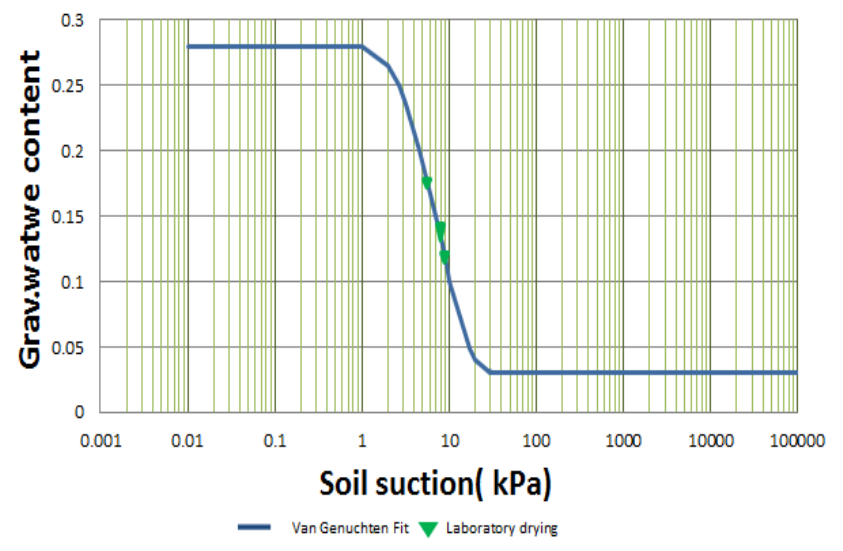

Figure 7. Gravitational water content and the matric suction relationship using soil vision software adopted by Van Genuchten equation [23].

There are two regions of changes in the slope of the SWCC, Fredlund et al. [21], explain that the changes in the slope define two focal points for SWCC. The first point is called "air entry value", the highest voids begin for saturation with increased suction. The other point is called "residual conditions," defined as a point for extrusion of water from the soil. It becomes considerably harder. Slope changes divided the SWCC across three zones, the border impact area in the low suction zone, the transference between the value of the air intake and the value of residual air, and the residual field.

Figures 6 and 7 showed good agreement with curves suggested by Fredlund Xing [22] and Van Genuchten [23]. The air enter value $\left(\mathrm{u}_{\mathrm{a}}-\mathrm{u}_{\mathrm{w}}\right)$ was $2.35 \mathrm{kPa}$ and $2.38 \mathrm{kPa}$, respectively. The equation proposed by Fredlund and Xing (1994) is given the most appropriate compared to other adopted methods in this study.

\section{Effect of Different Soil Conditions on Ultimate Up-Lift Resistance}

Uplift tests were performed on the screw pile models of different helices and pile shaft models under the different soil conditions (fully saturation, dry, and unsaturation of various matric suction) to investigate the ultimate uplift resistance of pile models. For uplift models, the ultimate resistance was defined by the peak points of the load-displacement curve.

Shaft pile under uplift load. Figure 8 shows the variation of uplift resistance for pile shaft only (without helices) under uplift load at different soil conditions. The results show that the uplift load increases as the matric suction increase. These increases are because the matric suction increases increase the effective stress.

Uplift Resistance of Single Helix Pile Model. Figure 9 demonstrates the behavior of the helical pile model (single helix) under the effects of lifting load at dry, fully saturation, and at various matric suction values of $(6.5,7.3$, and $9.6 \mathrm{kPa})$. Figure 9 shows the different behavior of the single helix pile model than pipe pile under uplift condition. In dry soil shows a lower value of uplift resistance, while partially saturated soil of $6.5 \mathrm{kPa}$ shows a higher uplift resistance than the other matric suctions. The reasons behind that due to the presence of water above the helix, which increases the resistance against uplift for fully saturation soils layers, and the increase in effective stress which introduce due to matric suction for the upper layer, the combination of these reasons gives higher resistance against uplift at $6.5 \mathrm{kPa}$ matric suction. 


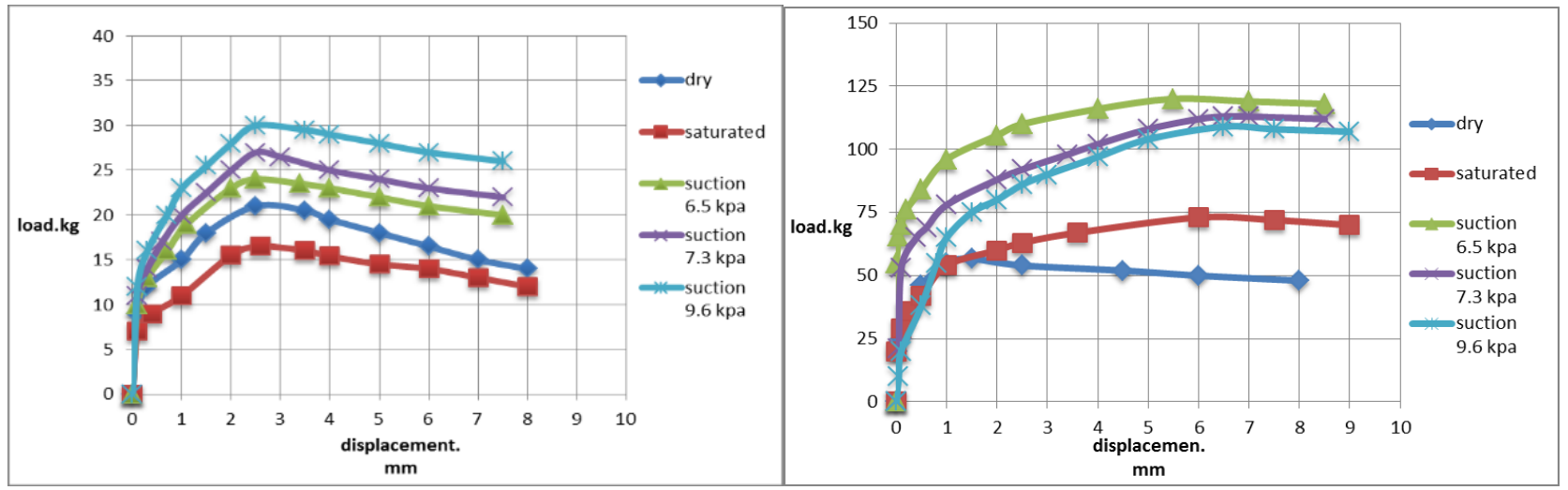

Figure 8. Load displacement relationships under uplift load for pipe pile at different saturation conditions.

Figure 9. Load displacement curve for helical pile (single helix), under uplift load at different soil conditions.

Uplift Resistance of Double Helices Pile Model. Figure 10 represents the behavior of the helical pile model of (double helices) under uplift load embedded within a soil of varying saturation conditions (dry, fully saturation, and unsaturation at matric suction values of $6.5,7.3$, and $9.6 \mathrm{kPa}$ ). Helical pile in dry soil shows lower values to uplift resistance, while partially saturated soil of $6.5 \mathrm{kPa}$ shows a higher uplift resistance than another matric suctions, which is the same behavior of single helix under uplift load.

Uplift Resistance of Triple Helices Pile Model. Figure 11 represents the behavior of a helical pile model with triple helices under the effects of lifting a load with various soil conditions (dry, fully saturation, and unsaturation at matric suction values of $6.5,7.3$, and $9.6 \mathrm{kPa}$ ). The results show that a helical pile in dry soil gives lower values of uplift resistance; while for partially saturated soil of matric suction, $6.5 \mathrm{kPa}$ shows a higher uplift resistance as in single and double helices higher uplift resistance.

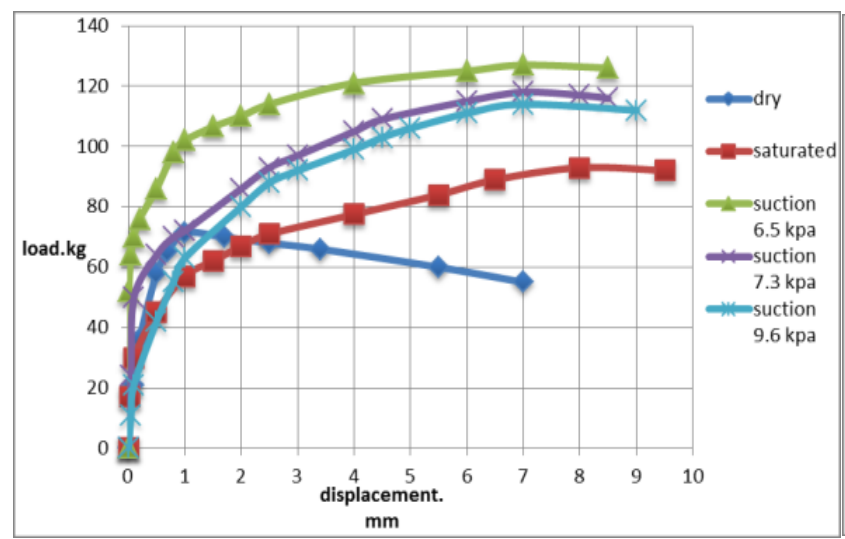

Figure 10. Load displacement curve for helical pile (double helix), under uplift load at different saturation conditions.

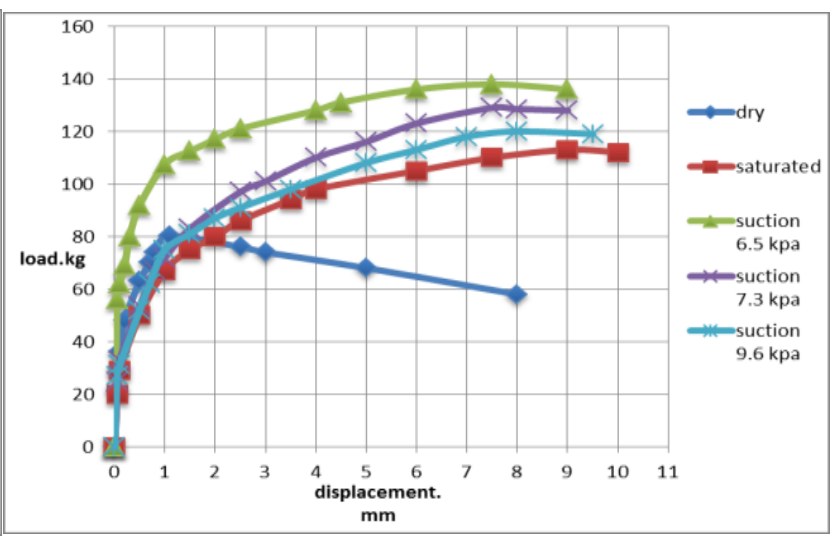

Figure 11. Load displacement curve for helical pile (triple helix), under uplift load at different saturation conditions.

Table 3 summarized the ultimate shaft pile, helical pile uplift resistance with single, double, and triple helices in fully dry and unsaturated soil. The maximum uplift resistance of helical piles within unsaturated soils is greater than those embedded within fully saturated and dry soils because of introducing effective stresses and gravity weight of water above the helices. The helical pile embedded within a soil of $6.5 \mathrm{kPa}$ matric suction gives higher uplift resistance than matric suction of $7.3 \mathrm{kPa}$ and $9.6 \mathrm{kPa}$. This is mentioned before due to the combined effect of saturation density and increase in effective stress to resist uplift of helical piles. When the soil is partially at matric suction of 7.3 and $9.6 \mathrm{kPa}$, there is a reduction in saturation density and an increase in effective stresses. 
Table 3. Ultimate uplift resistance values of helical pile models embedded whit in cohesionless soils of various Saturation conditions.

\begin{tabular}{|c|c|c|c|c|c|}
\hline \multirow{2}{*}{ The pile } & \multicolumn{5}{|c|}{ Soil saturation conditions } \\
\cline { 2 - 6 } & $\begin{array}{c}\text { Dry cond. } \\
(\mathbf{k g})\end{array}$ & $\begin{array}{c}\text { Fully sat. } \\
\text { Cond. } \\
(\mathbf{k g})\end{array}$ & $\begin{array}{c}\text { Unsaturated cond. } \\
\text { of } \mathbf{6 . 5} \mathbf{~ k P a} \text { Matric } \\
\text { suction }(\mathbf{k g})\end{array}$ & $\begin{array}{c}\text { Unsaturated cond. } \\
\text { of 7.3kPa Matric } \\
\text { suction (kg) }\end{array}$ & $\begin{array}{c}\text { Unsaturated cond. } \\
\text { of 9.6 kPa Matric } \\
\text { suction (kg) }\end{array}$ \\
\hline Pipe pile & 21.0 & 16.5 & 24.0 & 27.0 & 30.0 \\
\hline Single helix & 56.6 & 73.0 & 120.0 & 113.0 & 109.0 \\
\hline Double helices & 71.4 & 93.0 & 127.0 & 118.0 & 114.0 \\
\hline Triple helices & 80.3 & 113.0 & 138.0 & 129.0 & 120.0 \\
\hline
\end{tabular}

\section{Improvement Ratios in Uplift Resistance Due to fully and Unsaturation soil}

Table 4 demonstrates the increment ratios of uplift resistance of helical pile models embedded within various saturation conditions of cohesionless soils times than that of helical pile models embedded within dry soil. The results show that the increment ratios of ultimate uplift resistance of helical pile models embedded within unsaturation soil of matric suction 6.5 more than that of the ultimate resistance of fully saturation and unsaturation at matric suction of 7.3 and $9.6 \mathrm{kPa}$ for a different number of helices. According to the combined effect of saturation soil density, this is mentioned before and introduces the effective stresses due to lowering the water level. Figure 12 shows the increment ratio in ultimate uplift resistance of helical pile models due to fully and partially saturated soils times' dry condition.

Table 4. Increment ratios of ultimate uplift resistance of helical pile models embedded within various soil of saturation conditions times the ultimate uplift resistance of pile models embedded in dry soil.

\begin{tabular}{|c|c|c|c|c|}
\hline \multirow{2}{*}{ No. of helices } & \multicolumn{4}{|c|}{ Soil saturation conditions } \\
\cline { 2 - 5 } & $\begin{array}{c}\text { Fully } \\
\text { Sat. } \\
\text { cond. }\end{array}$ & $\begin{array}{c}\text { Unsaturated } \\
\text { cond. of 6.5 kPa } \\
\text { matric suction }\end{array}$ & $\begin{array}{c}\text { Unsaturated } \\
\text { cod. of 7.3 kPa } \\
\text { matric suction }\end{array}$ & $\begin{array}{c}\text { Unsaturated } \\
\text { cod. of 9.6 kPa } \\
\text { matric suction }\end{array}$ \\
\hline Single helix & 1.29 & 2.21 & 2.00 & 1.92 \\
\hline Double helices & 1.30 & 1.77 & 1.65 & 1.59 \\
\hline Triple helices & 1.40 & 1.71 & 1.60 & 1.50 \\
\hline
\end{tabular}

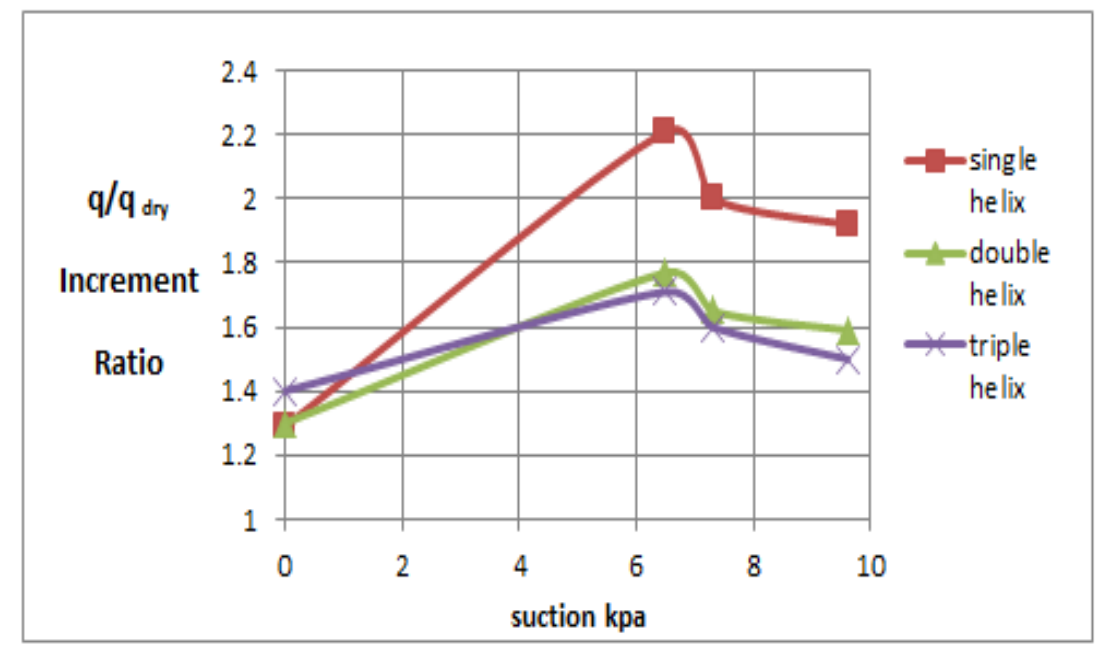

Figure 12. The increment ratios of uplift resistance for helical piles are embedded at fully and partially saturation soil than dry conditions. 
Table 4 shows that for helical pile with single helix embedded within partially saturated soil of matric suction, $6.5 \mathrm{kPa}$ shows higher uplift resistance about (2.2) times that helical pile of single helix within dry soil. While for helical piles with double and triple helices embedded within partially saturated soil of matric suction $6.5 \mathrm{kPa}$, the increment ratios were (2.0 and 1.9) respectively, which is less than that of the single helix. The increase of uplift resistance due to unsaturation soil under uplift significantly matched the other research test results [24-26, 28].

Effect Number of Helices on Uplift Resistance of Pile Models. Effect number of helices on the helical pile uplift resistance, embedded in various soil conditions (dry, saturated, and unsaturated) in Figures 13-17.

Uplift Resistance in Dry Soil. Figure 13 demonstrates the behavior of the various helical pile models embedded in dry soil. A figure shows an increase in uplift resistance with an increasing number of helices due to an increase in overburden pressure on the helical plates and increasing plate bearing area.

Uplift Resistance in Fully Saturated Soil. Figure 14 shows the behavior shows of the pipe pile and helical pile models, which are embedded within fully saturated soil conditions. A figure shows that the increasing of helices significantly affects increasing the uplift resistance with an increasing number of helices.

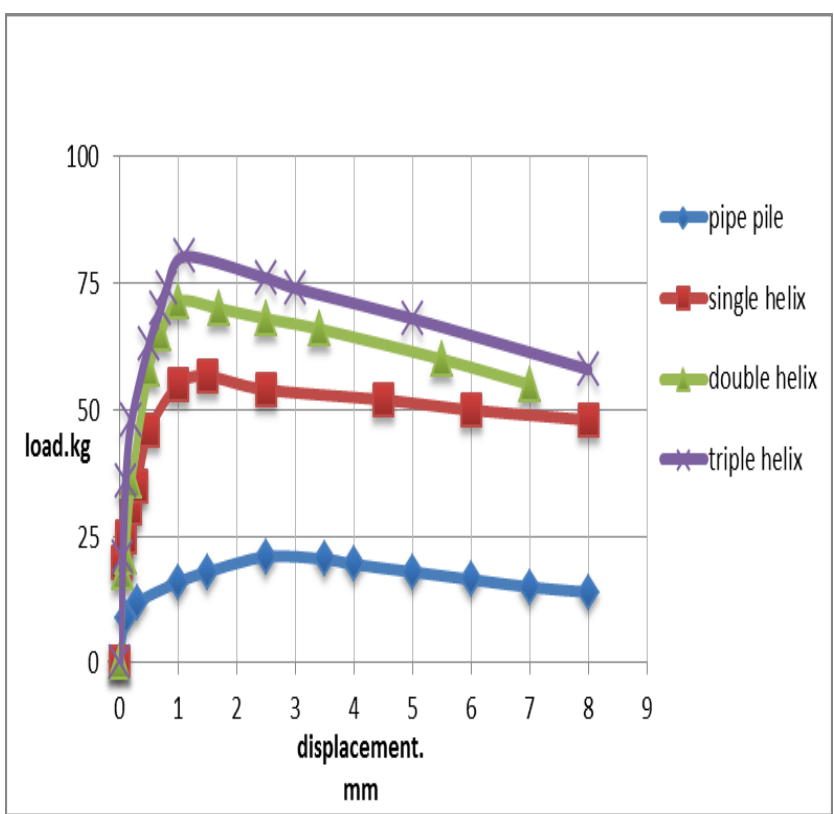

Figure 13. Load-displacement curve for pipe and Figure 14. Load-displacement curve for pipe and helical pile models embedded in dry soil for uplift resistance.

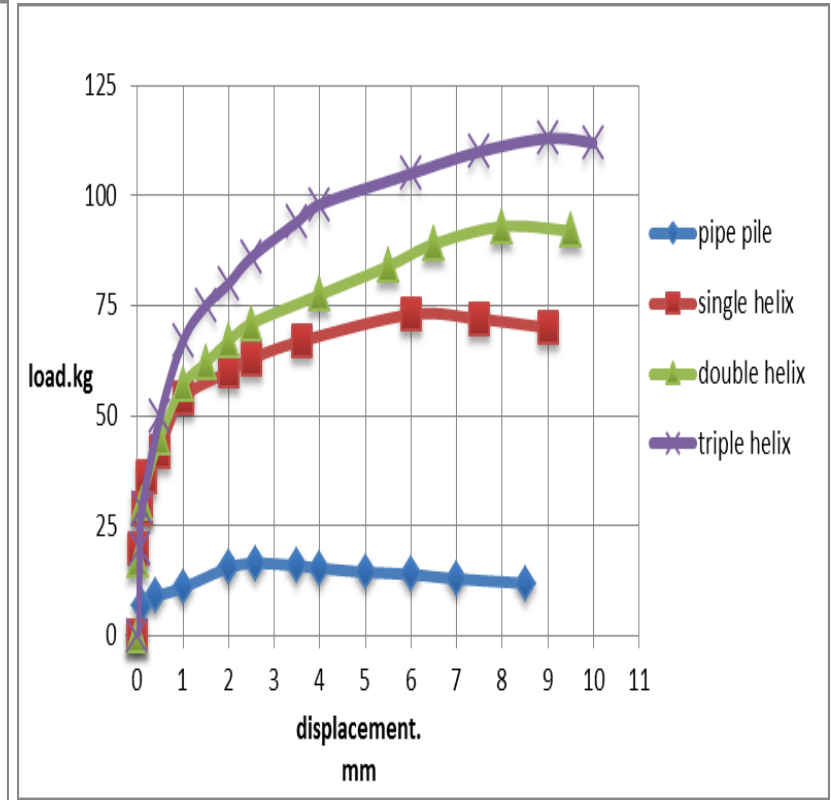

helical pile models embedded in fully saturation soil for uplift resistance.

Uplift Resistance in Partially Saturation Conditions. In this case, three models of different conditions of unsaturation were tested. Figures 15 to 17 show the behavior of the different pile model helices in unsaturated soils $(6.5,7.3$, and $9.6 \mathrm{kPa})$ with different matric suction, respectively. Figures show that the uplift resistance of helical pile models in unsaturated suction $6.5 \mathrm{kPa}$ gives higher uplift resistance than that of 7.3 and $9.6 \mathrm{kPa}$ matric suctions with an increasing number of helices. This is as mentioned before for the combined effect of saturation density and increasing effective stresses due to matric suction. 


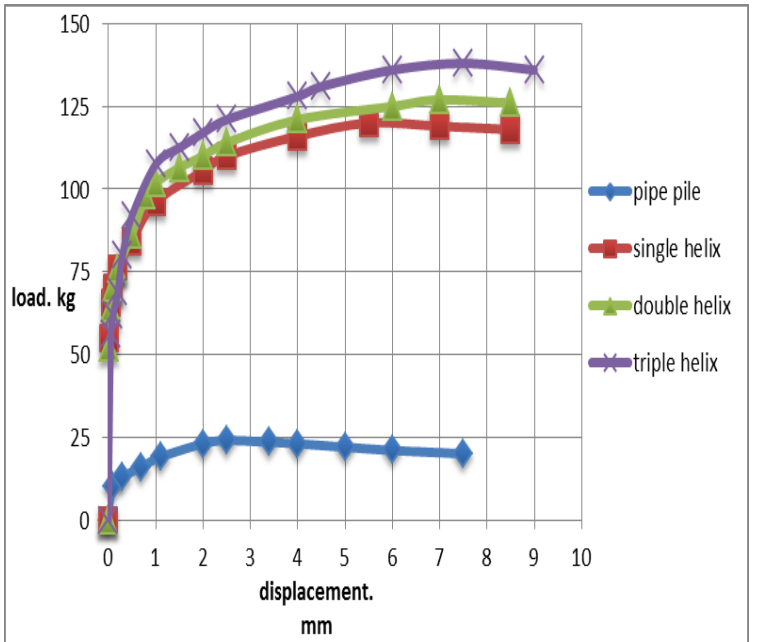

Figure 15. Load displacement behavior for pipe and helical pile models with different helices embedded within unsaturation soil of $6.5 \mathrm{kPa}$ suction, under uplift load.

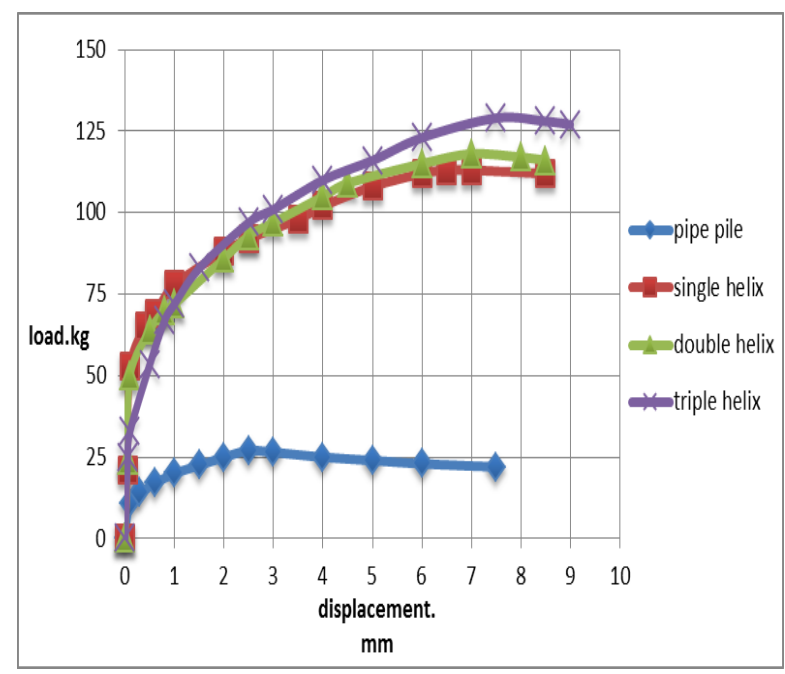

Figure 16. Load displacement behavior for pipe and helical pile models with different helices embedded within unsaturation soil of $7.3 \mathrm{kPa}$ suction, under uplift load.

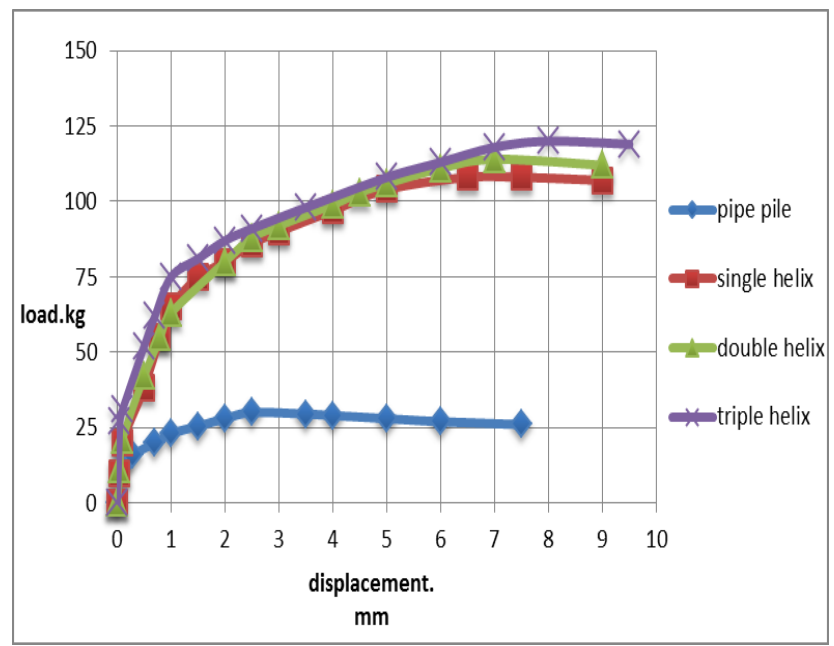

Figure 17. Load displacement behavior for pipe and helical pile models with different helices embedded within unsaturation soil of $9.6 \mathrm{kPa}$ matric suction, under uplift load.

Table 5. Increment of uplift resistance due to increase helices number various soil saturation conditions times the uplift resistance of pipe pile.

\begin{tabular}{|c|c|c|c|c|c|}
\hline \multirow{2}{*}{ No. of helices } & \multicolumn{5}{|c|}{ Soil saturation conditions } \\
\cline { 2 - 6 } & $\begin{array}{c}\text { Dry } \\
\text { cond. }\end{array}$ & $\begin{array}{c}\text { Fully sat. } \\
\text { cond. }\end{array}$ & $\begin{array}{c}\text { Unsaturated cond. } \\
\text { of 6.5 kPa } \\
\text { Matric suction }\end{array}$ & $\begin{array}{c}\text { Unsaturated cond. } \\
\text { of 7.3 kPa } \\
\text { Matric suction }\end{array}$ & $\begin{array}{c}\text { Unsaturated } \\
\text { Cond. of 9.6 kPa } \\
\text { Matric suction }\end{array}$ \\
\hline Single helix & 2.7 & 4.4 & 5.0 & 4.1 & 3.6 \\
\hline Double helices & 3.4 & 5.6 & 5.3 & 4.3 & 3.8 \\
\hline Triple helices & 3.8 & 6.8 & 5.7 & 4.7 & 4.0 \\
\hline
\end{tabular}

With respect to helical pile models embedded within dry soil, the percent of increases in uplift resistance of single, double, and triple helices than that of shaft pile approximately about 170, 240, and $282 \%$, respectively. For helical piles embedded within fully saturation soil, the percent of increments in uplift resistance for single, double, and triple helices than that of shaft pile approximately 342,463 , and $585 \%$. The results show that as a high increment in percentages increases the number of helices, the percent of increments in fully saturation soil is more than that in other soil 
saturation conditions. Concerning helical pile models embedded within unsaturation soils, which is conducted in various saturation conditions of $(6.5,7.3$, and $9.6 \mathrm{kPa})$ matric suction, the percent of increments in uplift resistance for single, double, and triple helices than that of shaft pile approximately about 400,429 , and $475 \%$ respectively for matric suction of $6.5 \mathrm{kPa}$, and 318,337 , and $377 \%$ respectively for matric suction of $7.3 \mathrm{kPa}$, and 263,280 , and $300 \%$ respectively for matric suction of $9.6 \mathrm{kPa}$. The results show that the maximum increment ratio for a pile of the single helix was at unsaturation soil of $6.5 \mathrm{kPa}$ matric suction, while for a helical pile of double helices was at fully saturation condition. For the helical pile of triple helices, the maximum rate of increment was at fully saturation condition also. Figure 18 shows the increment ratios of uplift resistance for helical pile with various helices embedded within different soil conditions of cohesionless soil than that of pile shaft. The figure shows the use of the extra helices gives high lifting resistance whether the soil was dry, saturated, or unsaturation. These results are identical [1]. These increments in uplift resistance are due to the resistance provided via the helices by providing multiple surface areas for the drawn load.

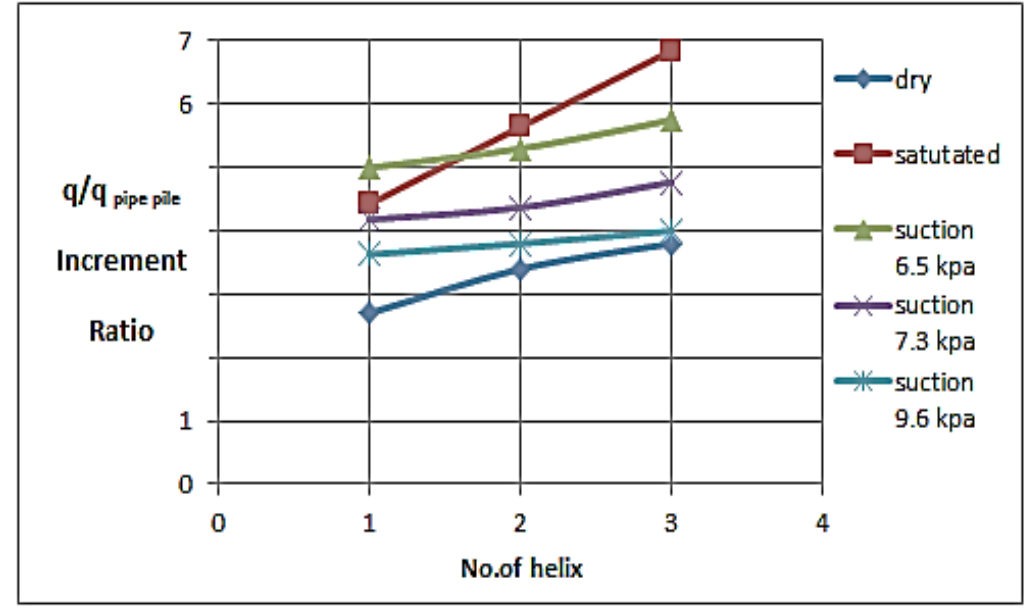

Figure 18. The increment ratios of uplift resistance for helical piles with different number of helices embedded within fully and unsaturation soil than that of pipe pile.

\section{Conclusions}

The main conclusions for this study can be summarizing as:

- The ultimate uplift resistance of pile model with different helices shows different behavior than shaft pile under uplift condition.

- The models of helical piles which are embedded within dry soil show lower values of uplift resistance than that embedded within unsaturated soil at $6.5 \mathrm{kPa}$ shows a higher uplift resistance than other matric suctions and for fully saturation soil also

- The increment ratios of uplift resistance for helical piles with a single helix within partially saturated matric suction of $6.5 \mathrm{kPa}$ show higher uplift resistance about (2.12) times within dry soil. While for helical piles with double and triple helices, the increment ratios less than that of single helix about (2.0 and 1.9), respectively.

- The ultimate uplift resistance of helical piles embedded within fully saturated is more significant than those embedded within dry soils.

- The numbers of helices significantly affect increasing uplift resistance, the increment of uplift resistance of helical pile with different helices embedded within different soil saturation conditions greater than that the uplift resistance of pipe pile.

- The uplift capacity for pipe pile embedded unsaturated soil condition increase with increase suction. The maximum uplift capacity of the pipe pile occurs when the matric suction equal to $9.6 \mathrm{kPa}$. 
- The improvement ratios of uplift resistance show that the helical piles give a higher resistance value to uplift load than that for compression load.

\section{References}

[1] Lutenegger, A.J., 2011. Behavior of multi-helix screw anchors in sand. In Proceedings of the 14th Pan-American Conference on Soil Mechanics and Geotechnical Engineering, Toronto.

[2] Al-Baghdadi, T.A., Brown, M.J., Knappett, J.A., and Al-Defae, A.H., 2017. Effects of vertical loading on lateral screw pile performance. Proceedings of the Institution of Civil EngineersGeotechnical Engineering, 170(3), pp.259-272.

[3] Zhang, D.J.Y., 1999. Predicting capacity of helical screw piles in Alberta soils. M.Sc. Thesis, Department of Civil and Environmental Engineering, University of Alberta.

[4] Vito, D. and Cook, T., 2011. Case histories on the use of helical piles for retrofitting and new construction. 2011 Pan-Am CGS. In Geotechnical Conference, Canada.

[5] Perko, H.A., 2009. Helical piles: a practical guide to design and installation. John Wiley \& Sons.

[6] Sakr, M., 2009. Performance of helical piles in oil sand. Canadian Geotechnical Journal, 46(9), pp.1046-1061.

[7] Rao, S.N., Prasad, Y.V.S.N. and Shetty, M.D., 1991. The behaviour of model screw piles in cohesive soils. Soils and Foundations, 31(2), pp.35-50.

[8] Aydin, M., Bradka, T.D. and Kort, D.A., 2011. Osterberg cell load testing on helical piles. In GeoFrontiers 2011: Advances in Geotechnical Engineering (pp. 66-74).

[9] Tappenden, K., Sego, D. and Robertson, P., 2009. Load transfer behavior of full-scale instrumented screw anchors. In Contemporary Topics in Deep Foundations (pp. 472-479).

[10] Lutenegger, A.J., 2009. Cylindrical shear or plate bearing? Uplift behavior of multi-helix screw anchors in clay. In Contemporary Topics in Deep Foundations (pp. 456-463).

[11] Fattah, M.Y., Salim, N.M. and Mohsin, I.M., 2014. Behavior of single pile in unsaturated clayey soils. Engineering and Technology Journal, University of Technology, 32(Part (A), pp.763-787.

[12] Fredlund, D.G. and Rahardjo, H., 1993. Soil mechanics for unsaturated soils. John Wiley \& Sons.

[13] Gallipoli, D., Gens, A., Sharma, R. and Vaunat, J., 2003. An elasto-plastic model for unsaturated soil incorporating the effects of suction and degree of saturation on mechanical behaviour. Géotechnique, 53(1), pp.123-135.

[14] Smith, I., 2014. Smith's elements of soil mechanics. John Wiley \& Sons.

[15] Richards, B.G., 1974. Soil mechanics - new horizons. chapter 4: behaviour of unsaturated soils. Butterworth and Company Publishers Limited, pp. 112-157.

[16] Brady, N.C., Weil, R.R. and Weil, R.R., 2008. The nature and properties of soils (Vol. 13, pp. 662-710). Upper Saddle River, NJ: Prentice-Hall.

[17] ASTM D854-00, 2000. Standard test method for specific gravity of soil solids by water pycnometer. Annual book of ASTM standards.

[18] ASTM D422-00, 2000. Standard test method for particle size analysis of soil. American Society of Testing and Materials.

[19] ASTM D4253-00, 2000. Standard test method for maximum index density and unit weight of soils using a vibratory table. American Society of Testing and Materials.

[20] ASTM D4254, 2000. Standard test method for minimum index density and unit weight of soils and calculation of relative density. American Society for Testing and Materials.

[21] Fredlund, D.G., Sheng, D. and Zhao, J., 2011. Estimation of soil suction from the soil-water characteristic curve. Canadian geotechnical journal, 48(2), pp.186-198.

[22] Fredlund, D.G. and Xing, A., 1994. Equations for the soil-water characteristic curve. Canadian geotechnical journal, 31(4), pp.521-532.

[23] Van Genuchten, M.T., 1980. A closed-form equation for predicting the hydraulic conductivity of unsaturated soils. Soil science society of America Journal, 44(5), pp.892-898. 
[24] Georgiadis, K., Potts, D.M. and Zdravkovic, L., 2003. The influence of partial soil saturation on pile behaviour. Géotechnique, 53(1), pp.11-25.

[25] Mohamed, F.M.O. and Vanapalli, S.K., 2006, October. Laboratory investigations for the measurement of the bearing capacity of unsaturated coarse-grained soil. In Proceedings of the 59th Canadian geotechnical conference, Vancouver (pp. 219-226).

[26] Ravichandran, N. and Shada, H.K., 2010. Dynamic Response of Pile Foundation in Partially Saturated Soils. In GeoFlorida 2010: Advances in Analysis, Modeling \& Design (pp. 30093018).

[27] Vanapalli, S.K. and Taylan, Z.N., 2012. Design of single piles using the mechanics of unsaturated soils. International Journal of GEOMATE, 2(1), pp.197-204. 